DOI https://doi.org/10.18551/rjoas.2018-04.10

\title{
THE EFFECT OF GOVERNMENT EXPENDITURE AND PRIVATE INVESTMENT ON WORK OPPORTUNITIES AND UNEMPLOYMENT RATE IN INDONESIA
}

\author{
Sun'an Muammil \\ Faculty of Economics, University of Khairun, Ternate, Indonesia \\ E-mail: amilsunan78@gmail.com
}

\begin{abstract}
This study aims to analyze the effect of government expenditure and private investment on employment and unemployment in Indonesia, and employment opportunities on the unemployment rate in Indonesia. The path analysis is used as a method of data analysis. The results show that government expenditure and private investment have a significant and positive correlation to employment; this means that an increase in government expenditure and private investment will increase employment as well. Furthermore, private investment has a significant and negative correlation to the unemployment rate; this means that, an increase in private investment will reduce the unemployment rate. Government expenditure has no effect on unemployment rate in Indonesia because government expenditure focuses on the development of basic infrastructure and has not yet targeted the economic activities of the community.
\end{abstract}

\section{KEY WORDS}

Government expenditure, private investment, employment opportunities, unemployment.

The increasing number of our population, to date Indonesia's population is estimated to reach 250 million people (Sudibyo, 2013), has become one of the causes of the high rate of unemployment in Indonesia. Central Bureau of Statistics estimates that Indonesia's population will continue to increase to 273.2 million people in 2025 . However, this high number does not make Indonesia as one of the countries with good quality human resources. The quality of good human resources depends on the education achieved by a person or a society. According to Purnomo (2010), quoting Suparno (2009), the human resource factor becomes important as it determines the competitive advantage of a country.

Keynes in Sukirno (2008) states that the role or intervention of the government is indispensable if the economy is fully regulated by a free market activity, as the economy does not reach full employment levels nor it reaches such stability. One form of intervention is through a fiscal policy. In this case, Keynes implies expansive fiscal policy through tax reductions and the addition of government expenditure.

Zulhanafi et al. (2013) suggest that government spending significantly affects unemployment. If government expenditure increases, like capital expenditure to improve infrastructure, it will increase output, and the increased output will increase the demand for factors of production, one of which is labor; thus, such a situation would lead to a decrease in the unemployment rate. Conversely, if government spending decreases, it will hamper the process of production of goods and services (output) so demand for factors of production will also decrease causing the unemployment rate to increase.

In addition, investment from private parties also determines the production or economic activities that will improve the welfare of the community (Tjiptoherijanto, 1996). Investment is a factor affecting economic development, as it affects employment opportunities. Investment will encourage production process (output) and output needs human resources in the process. Thus, the relationship between investment and employment is close.

The amount of investment in a country or region describes the amount of economic activity, and the economic activity illustrates the production process. Investment is crucial for the sustainability of economic development or long-term economic growth. Production activities create job opportunities and increased community income, which in turn increases market demand (Tambunan, 2001). 
Based on these explanations above, then the research problems are:

- Do government expenditure and private investment affect employment opportunities in Indonesia?

- Do government expenditure and private investment affect the unemployment rate in Indonesia?

- Do job opportunities affect the unemployment rate in Indonesia?

\section{LITERATURE REVIEW}

Unemployment Definition. Unemployment happens when one does not have a job but he/she is actively looking for one in the last four weeks (Kaufman and Hotchkiss, 1999). Unemployment is a situation where a person belonging to the workforce wants to get a job but they have not had the chance (Sukirno, 1994). Unemployment may occur due to an imbalance in the labor market. This indicates that the number of labor offered exceeds the amount of labor demanded.

According to Kuncoro (2000), using the labor force approach, unemployment is divided into three types. The first type is frictional unemployment, a type that arises because workers are still looking for suitable jobs. One is unemployed not because there is no job. This unemployment is not a problem and can be solved with economic growth. The second type is structural unemployment, a type of unemployment that arises due to changes in structure and economic conditions. Unemployment is difficult to overcome because it is associated with a country's development strategy. However, this unemployment can be overcome by conducting training to create skilled labor. The third is seasonal unemployment, i.e. unemployment occurs due to seasonal factors, for example, industrial workers who rely on orders. This unemployment also does not cause problems although there is no empirical evidence to support it.

Samuelson (1992) defines unemployment (unemployed) as a person who is not working but keen to find a job or being called back to work in his/her previous place of work. In other words, someone is said to be unemployed if he or she is not working and (a) trying to find a job for the last four weeks, (b) just being discharged from work and waiting to be recalled, or (c) preparing for a job application for the following month. In addition, there is involuntary unemployment and voluntary unemployment. Voluntary unemployment is those who do not want to work at the prevailing wage rate in the labor market; this group does not want to work because of low wages or other factors such as high levels of education that tend to choose to become unemployed rather than work with low wages. Involuntary unemployment are those who are not absorbed in economic activity because of limited job opportunities.

Unemployment Types. Here is the list of unemployment based on the types:

- Open unemployment-it is a type that emerges because of lower employment growth than workforce growth, resulting in more and more workers not getting jobs. These workers in the end are not included in economic activities; they are unemployed in a real and full time.

- Underemployment-it is a situation where workers work under normal working hours, usually about 36 hours per week. Those who work less than the working hours are grouped into underemployed groups.

- Disguise unemployment-it is a type that arises because the number of workers in an economic activity is more than the actual needs to produce efficient production. In theory, this arises because the Marginal Productivity of the company is below zero but the company or organization keeps adding workers due to various considerations.

- Seasonal unemployment-this mostly occurs in the agricultural sector. For example, during the rainy season, fisherman, and rubber tapper cannot work. This also happens to farmers during the dry season.

Employment Opportunities. Economists often argue that the macroeconomic has four main objectives: a) achieving and maintaining full employment, b) maintaining price stability, 
c) increasing economic growth (national income growth), and d) achieving international balance of equilibrium (Suparmoko; 2000).

Full job opportunities are in demand as it uses all production factors, which means a higher number of goods and services available to the community. Expenses arising from unemployment and loss of goods and services of an economy are borne by different groups of people, especially those who have lost their jobs. Thus, the society does not want some people suffering from job loss. Unemployment is not only about the source of life, but also about the prestige or self-esteem of a person in society; it even can disrupt the social balance.

Population growth is quite high in Indonesia and the labor force exceeds the existing employment opportunities. Such a situation leads to less labor demand from labor supply; it will eventually lead to unemployment and low wage rate.

The demand for labor depends on the available employment opportunities in the economy as a whole. Factors influencing labor demand are the growth of saving and investment, both domestic and foreign. The greater the savings, credit, and capital exploited for industrial expansion, the better the growth of the industry, i.e. the products are increasing. Industrial expansion requires the addition of work force, which means increasing employment opportunities (Sartika, 2005).

The low economic growth rate is even made worse with high population growth; the two affects much on the welfare of society. High population growth is positively correlated with workforce growth; if the economy has not enough capacity to absorb labor, it will give rise to various economic problems significant to the economy as a whole. The welfare of the community must become a priority for the government. Thus the level of community welfare can be known from the level of aggregate demand.

Employment Opportunities and Investment. Theorists and development practitioners respond varies to the issue of investment. The opinion on the importance of investment in supporting the development of developing countries began with the discovery of the growth model after World War II in the 1950s and 1960s by some development experts such as Rostow and Harrod-Domar. According to Rostow, any attempt to take-off requires the mobilization of domestic and foreign savings with the intent to create sufficient investment to accelerate economic growth. Harror-Domar argues that national income growth is positively related to savings ratio, and vice versa, negatively associated with COR or ICOR (Capital Output Ratio or Incremental Capital Output Ratio) (Todaro, 2000).

Investment is a key determinant of economic growth; it will boost output significantly and will automatically increase demand for inputs, which in turn will increase employment and public welfare as a consequence of increased incomes received by the community (Makmun \& Yasin, 2003 ).

Investment should be seen as the main driving force for economic growth, creating employment opportunities and enhancing international competitiveness rather than simply covering shortages of financing (Sinar Harapan, 2003). Thus, investment is expected as a resource mobilization to create or increase production capacity or income in the future. According to Lewis (1993), investment is the demand for goods and services to create or increase production capacity or income in the future. Investment has two main objectives, i.e. replacing part of the damaged capital (depreciation) and adding amount to the existing capital or net investment. Investment is the most frequent element of GRDP. When expenditure on goods and services falls during a crisis, a large part of the decline is due to a drop in investment expenditure.

Then according to Dornbusch (1999), investment is an expenditure intended to increase or maintain stock of capital goods. The capital stock consists of factories, machinery, offices, and other durable products used in the production process. Capital goods also include residential housing and supplies. Investment is the expenditure added to the components of this capital goods.

Investment expenditure is intended to gain profits from the investment expenditure. Investment is the second largest expenditure component after consumption; although investment expenditure is smaller than consumption expenditure, the unstable nature of 
investment expenditure makes an increase (fluctuations) at the level of income, output, and employment. The motive of the investment is to make a profit from the Investment. Two important factors that determine investment success are the level of net profit expected by the company from investment expenditure and interest rate factors (Wijaya, 1997). Economic growth will lead to increased public incomes. In economic theory, people's income will be spent on consumption and the rest is on saving. These savings will be lent to entrepreneurs for investment purposes (Arsyad, 1999).

Associated with the above conditions, investment can be seen as having two sides. The first side affects the level of national income and employment rate, while the other side affects the national production capacity. The first premise or effect of the investment (Keynes's cross-sectional model), IS-LM, and aggregative supply demand in principle discuss the first investment effect, while the second investment effect is the main subject of the theory of economic growth known as Growth Theory (Reksoprayitno, 2000).

Opportunities and Government Expenditures. In the economic perspective, fiscal policies have various objectives in directing the country's economic activity, namely to increase economic growth, to stabilize the country, to make equitable distribution of income, and to increase employment opportunities (Dornbusch and Fisher; 1994; Taggart et al., 2000). Nevertheless fiscal policies have such a big impact on economic activities. The direct impact of government activities on the state economy can be seen from the government spending; thus, mismanagement of government expenditure will be harmful for the economy of the country.

Another problem that may be caused by fiscal policy inappropriateness is crowding out, meaning that increased government spending will actually decrease private investment (Chang et al., 2002). Thus it can said that an increase in the budget deficit may also result in the growth of subsequent government spending (Ahmed and Kenneth, 2000). Increased government spending can have an impact on various macroeconomic indicators of the country. To make the country's economic activity at its optimum level with the support of the private sector, an efficient fiscal management and an optimum level of government expenditure are both required. The process of such mechanisms occurs continuously so that the country's economy is experiencing glory (Arestis et.al., 2002).

If government spending is able to guide the country's economy, an increase in government spending will increase economic activities with increased investment. Increased investment will also have an impact on increasing output, employment, exports, taxes, government revenue, and current transactions (Sriyana, 2006).

The causal relationships that exist in macroeconomics are principally the relationships of aggregative economic variables, among which many are questioned, such as national income, employment, household consumption, saving, national investment, money supply, international balance, national capital stock, and government debt. The relationship between the variables above is used to solve the existing problems. For example, to reduce unemployment, government expenditure should be increased, or otherwise, to increase government spending then unemployment rate must be reduced. Thus, there is a causal relationship between the increase in government expenditure and the decrease in unemployment and also a relationship between the decrease of taxes with unemployment (Reksoprayitno, 2000).

According to Barro (1997), fiscal policies have a role to influence steady state growth; the theory implies a relationship between government size, growth rate, and savings. Barro divides the model into two, productive and non-productive government expenditure. Variations in the share of productive government expenditure have a positive impact on economic growth and savings. Meanwhile, unproductive government expenditure decreases economic growth; the reason is that unproductive government spending has no direct effect on the productivity of the private sector so there is no stimulus to invest that causes the slow growth in the economy due to lack of investment. 


\section{METHODS OF RESEARCH}

The data used in the analysis includes quantitative data, with secondary data sources including data on: Government expenditures; Private investment; Employment opportunities; Unemployment rate.

Secondary data sources are related institutions, such as Capital Investment Coordinating Board, the Workforce Office or Central Bureau of Statistics, as well as reports related to this study.

This study uses time series data from 2010 to 2015 and path analysis. Path analysis is used to explain the relationship between variables with an intervening variable with the aim to know the direct or indirect effect of a set of independent variables (exogenous) to the dependent variable (endogenous) (Riduwan and Sunarto, 2015). The equation used is as follows:

$$
\begin{gathered}
Y_{1}=\beta_{0}+\beta_{1} X_{1}+\beta_{2} X_{2}+\varepsilon_{1} \\
Y_{2}=\beta_{0}+\beta_{3} X_{1}+\beta_{4} X_{2}+\beta_{5} Y_{1}+\varepsilon_{2}
\end{gathered}
$$

Where:

$\mathrm{X}_{1}=$ Government expenditure;

$\mathrm{X}_{2}=$ Private Investment;

$\mathrm{Y} 1$ = Employment Opportunity;

Y2 = Unemployment;

$\beta_{1} \ldots \beta_{5}=$ Regression coefficient of independent variables $\left(X_{i}\right)$;

$\beta_{0}=$ Intercept / Constants;

$\varepsilon_{1}=$ Error of the first equation;

$\varepsilon_{2}=$ Error of the second equation.

\section{RESULTS AND DICUSSION}

Results of Path Analysis. Based on the data, calculation or data processing was then done using SPSS program. Here is the summary of path analysis

Table 1 - The Results of the Path Analysis

\begin{tabular}{|c|c|c|c|c|c|}
\hline $\begin{array}{c}\text { Relationship } \\
\text { among variables }\end{array}$ & Beta Path Coefficient & $\mathrm{t}$ Value & \multirow{2}{*}{$\mathrm{F}$ Value } & $\begin{array}{c}\text { Determination } \\
\text { Coefficient }\left(\mathrm{R}^{2}\right)\end{array}$ & Note \\
\hline X1 against $Y 1$ & 0.004 & 3.930 & \multirow{2}{*}{27.792} & \multirow{2}{*}{0.778} & Significant \\
\cline { 1 - 3 } X2 against $Y 1$ & 4.305 & 4.867 & & & Significant \\
\hline X1 against $Y 2$ & -0.052 & -1.815 & \multirow{2}{*}{5.146} & \multirow{2}{*}{0.807} & Sot Significant \\
\cline { 1 - 3 } X2 against $Y 2$ & -82.189 & -2.846 & & Significant \\
\hline Y1 against $Y 2$ & -11.342 & -2.653 & & & Significant \\
\hline
\end{tabular}

Note:

$X 1=$ Government expenditure, $Y 1=$ Employment Opportunity, $X 2=$ Private investment, $Y 2=$ Unemployment .

The above table describes the first equation of the regression model with individual or partial test. For the relationship of government expenditure and employment opportunities, the $t$ value is 3.930 and significance value is 0.013 ; because the significance value is $<0.05$ (the probability value), then $\mathrm{H}_{0}$ is rejected and $\mathrm{Ha}$ is accepted. This means that government expenditure has a significant effect and positive correlation to employment opportunities in Indonesia. For the relationship of private investment and employment, the $t$ value is 4.867 and significance value is 0.006 ; because the significance value is $<0.05$ (the probability value), then $\mathrm{H}_{0}$ is rejected and $\mathrm{Ha}$ is accepted. This means that private investment has a significant effect and positive correlation to employment opportunities in Indonesia.

Then, we proceeds with the second equation of the regression model with individual or partial test. For the relationship of government expenditure and unemployment, the $t$ value is 1.815 and significance value is 0.084 ; because the significance value is $>0.05$ (the 
probability value), then $\mathrm{H}_{0}$ is accepted and $\mathrm{Ha}$ is rejected. This means that government expenditure has no significant effect and has a negative correlation to unemployment in Indonesia. For the relationship of private investment and unemployment, the t value is 2.846 and significance value is 0.001 ; because the significance value is $<0.05$ (the probability value), then $\mathrm{H}_{0}$ is rejected and $\mathrm{Ha}$ is accepted. This means that private investment has a significant effect and positive correlation to unemployment in Indonesia.

\section{DISCUSSION OF RESULTS}

The Effect of Government Expenditure on Employment Opportunities in Indonesia. In the economic perspective, fiscal policies have various objectives in directing the country's economic activity, namely to increase economic growth, to stabilize the country, to make equitable distribution of income, and to increase employment opportunities (Dornbusch and Fisher; 1994; Taggart et al., 2000). According to Barro (1997), fiscal policies have a role to influence steady state growth; the theory implies a relationship between government size, growth rate, and savings.

The results of the study show that government expenditure has a significant and positive correlation to employment in Indonesia. This is in line with research conducted by Wahyuni (2004) examining the role of government in economic growth in 20 Asia-Pacific countries with similar economic backgrounds from 1980 to 2000. The study shows that the coefficient share of government expenditure on GDP is negative. Furthermore, the results of the study also show that government expenditure has a positive effect on employment in Indonesia. This means that if the government raises its expenditure (fiscal expansion), it will create an increase in employment opportunities in every region in Indonesia. The total government expenditure is the total income of the community. Similarly, government expenditure will increase aggregate demand and through the demand, production or aggregate supply will increase so employment can be recognized through the size of the government expenditure multiplier (Boediono, 1998).

The direct impact of government activities on the state economy is attributed to the size of government expenditure; thus, if the management of government expenditure is not good, it will harm the economy. If government expenditure is able to guide the improvement of the country's economy, an increase in government expenditure will increase economic activities with increased investment. The increase in investment will increase output, employment, exports, taxes, government revenue, and current transactions (Sriyana, 2006).

The Effect of Private Investment on Employment Opportunities in Indonesia. One important indicator for analyzing the economic development in a country is economic growth, as measured by the difference in gross domestic product of a year with the previous year (Setiawan \& Handoko, 2005). More specifically, Todaro (2000) mentions that the accumulation of capital and population growth associated with the amount of labor force and technological progress is a major component of economic growth. Capital accumulation will occur if part of present income is saved and invested to enlarge the output in the future. According to Adam Smith (in Kuncoro, 1997), the accumulation of capital will determine the rapid or slow economic growth in a country. The capital is collected from the savings made by the community. The accumulation of capital generated from savings helps the economic actors to invest into the real sector, in an effort to increase its income.

The results of the study indicate that private investment has a positive and significant effect on employment in Indonesia. This means that an increase in private investment will increase employment opportunities in Indonesia. However, investment has no effect on employment opportunities in Indonesia. This is in line with the theory that investment is a key determinant of economic growth, as in addition to create significant output increases, it will also automatically increase input demand, which in turn will increase employment and public welfare as a consequence of rising incomes accepted by the society (Makmun and Yasin, 2003).

The Effect of Government Expenditure on Unemployment in Indonesia. In the economic perspective, fiscal policies have various objectives in directing the country's 
economic activity, namely to increase economic growth, to stabilize the country, to make equitable distribution of income, and to increase employment opportunities (Dornbusch and Fisher; 1994; Taggart et al., 2000). If government expenditure is able to direct the improvement of the country's economy, an increase in government expenditure will increase economic activities with increased investment. Such an increase in investment will also increase employment opportunities (Sriyana, 2006).

The results of the study indicate that government expenditure has no significant effect and is negatively correlated to unemployment in Indonesia. This means that an increase in government expenditure still cannot reduce the unemployment rate. This is because government expenditure still focuses on the development of public infrastructure that has no direct relationship with the economic activities of the community. The results of this study are contrary to Rum's (2007), entitled "An Analysis of the Factors Affecting Open Unemployment in Indonesia from 1980 to 2007", where government expenditures have a negative and significant impact on unemployment. This means that the higher government expenditure, the lower open unemployment will be.

The Effect of Private Investment on Unemployment in Indonesia. Investment is a determinant of economic growth, because, in addition to driving significant output increases, it also increases input demand, which in turn will increase employment and community welfare because of the increased income received by the society (Makmun and Yaksin, 2003). Investment causes an increase in the production of goods, which also affects labor demand; this leads to increased employment to reduce unemployment. The existence of investments will encourage the creation of new capital goods that will absorb new production factors, i.e. creating new jobs or employment opportunities that will absorb workforce, which in turn will reduce unemployment (Prasojo, 2009).

The results of the study indicate that private investment has a significant and negative correlation to unemployment in Indonesia; this means that an increase in private investment will reduce the level of open unemployment in Indonesia. This is in line with Harrod-Domar's theory that looks at the effect of investment in a long time perspective. According to these two economists, investment expenditure (I) not only has an effect (through a multiplier process) on the aggregate demand (Z), but also on the aggregate supply (S) through its effect on production capacity in order to reduce unemployment rate (Boediono, 1999). The amount of investment in an area will certainly have an impact on the number of unemployed in the area, as the investment will help to expand business through an increase in the capital used and labor used. Thus, it is expected that investment can reduce the number of unemployment.

According to Pratiwi (2005), investment that has a multiplier effect has an impact on the improvement of welfare, as measured by the increase of income. This means that if the income increases, the amount of goods and services consumed will increase as well. If the demand for goods and services increases, it will increase employment opportunities and reduce the unemployment rate. Reduced unemployment is due to the absorption of the labor force in investment projects.

\section{CONCLUSION AND SUGGESTIONS}

Based on the findings and discussion, the following conclusions are drawn:

Government expenditure affects employment in Indonesia, but it does not affect unemployment. This means that if the government raises its expenditure (fiscal expansion), it will increase employment opportunities. However, the considerable government expenditure on infrastructure development makes it not yet able to reduce the unemployment rate.

The results show that private investment has a positive and significant impact on employment and unemployment in Indonesia. This means an increase in private investment will increase employment opportunities and decrease unemployment at the same time.

Suggestions:

Considering that government expenditure has no effect on unemployment, the policy must be made to support investment, so (private) entrepreneurs will be more inclined to 
expand their business, which tend to create employment opportunities. However, government-financing policies should be more directed development or community empowerment.

Investment and government expenditure are both important in economic development so the government needs to revise the allocation of expenditure; expenditure should be focused on productive aspects. The government must also revise the amount or percentage of taxes for the industrial sector, as it will affect the cost of input or production capacity, thus reducing employment opportunities.

\section{REFERENCES}

1. Arestis, Philip., Mosahid Khan, dan Kul B. Luintel, 2002, Fiscal Deficits in Monetary Unions: A Comparasion of EMU and United States, Eastern Economic Journal, Vol.1, No. 1, Winter : $89-104$.

2. Assyadin. F, Wijaya F, 2001, Pertumbuhan Ekonomi dan Kesempatan Kerja : Terapan Model Kebijakan Prioritas Sektoral untuk Kalimantan Timur. Jurnal Riset PPAM STIE "Yo", Vol. 1, No. 1 hal. 99 - 100.

3. Barro, Robert J, 1997, Determinants of Economic Growth, A Cross-Country Empirical Study, The MITT Press Cambridge, Massachusetts, $14-47$.

4. Chang,Tsang Yao, Wen Rong Liu dan Henry Thompson, 2002, The Vaiability of Fiscal Policy in South Korea, Taiwan and Thailand, ASEAN Economic Bulletin, Vol .19, No. 2 : $170-177$

5. Dornbusch, Rudiger dan Stanley Fischer, 1987, Makro Ekonomi, Alih Bahasa J. Mulyadi, Edisi Keempat, Penerbit Erlangga, Jakarta.

6. Haryanto, Junison, 2005, Analisis Hubungan Antara Pertumbuhan Ekonomi dan Investasi Pemerintah di Kabupaten Musi Banyuasin, Kajian Ekonomi, Jurnal Penelitian Bidang Ekonomi, Vol.4, No.1, 56 - 80, PS - UNSRI, Palembang.

7. Kauffman, Bruce E., Julie L. Hotchkiss. 1999. The Economic of Labor Markets. Fifth Edition, USA: The Dryden Press, Harcourt College Publiser.

8. Lipsey Richard G, Paul R Cournot, and Cristoper TS Ragan, 2007. Economics, AddisoWsley Publishing Company, Inc.

9. Makmun, Akhmad Yasin, 2003, Pengaruh Investasi dan Tenaga Kerja Terhadap PDB sektor Pertanian, Kajian Ekonomi dan Keuangan, Vol.7, No.3 : 63.

10. Mankiw, N. Gregory. 2000. Teori Makro Ekonomi: edisi keempat. Jakarta: Erlangga.

11. Mankiw, N.G., D.Romer. 1992. A Contribution to The Empirics of the Economic Growth. Quarterly Journal of Economics, 127(2): h: 407-437.

12. Nelson, C. Arthur, William P. Drummond and David S. Sawichi, 1994, Economic Base : Analysis of Employment Trends by Economic Sector. Economic Development Review : $23-26$.

13. Pratiwi, Fajar. 2005. Faktor-Faktor Yang Mempengaruhi Investasi Swasta Domestik Di Provinsi Jawa Barat 1975-2003. Yogyakarta. Tesis S2. Program Pasca Sarjana UGM.

14. Purnomo, A., \& Sukamdi. 2010. Karakteristik penganggur terbuka, setengah penganggur dan pertumbuhan ekonomi di propinsi Jawa Timur (analisis data sakernas Agustus tahun 2010). Jurnal Bumi Indonesia 1, 1-10.

15. Reksohadiprodjo, Sukanto, 1999, Ekonomika Publik, Edisi Pertama, BPFE, Yogyakarta.

16. Reksoprayitno, Soediyono, 2000, Ekonomi Makro, Analisis IS - LM dan Permintaan Penawaran Agregat, Edisi Millennium, Liberty,Yogyakarta.

17. Rum, Moch. Alim. 2007. Analisis Faktor Penentu Pengangguran Terbuka Di Indonesia Periode 1980-2007. Jurnal Kajian Politik Dan Masalah Pembangunan Ekonomi, Vol.4, No.1, 2008.

18. Salvatore, Dominick. 1997. Teori Mikro Ekonomi Edisi Ketiga. Jakarta: Erlangga.

19. Samuelson, Paul A and William P Nordhaus. 1997. Mikro Ekonomi. Jakarta: Erlangga.

20. Samuelson Paul A dan William Nordhaus, 2004. Ekonomi, Erlangga, Jakarta.

21. Sriyana, Jaka. 2006, Deficit Financing di Indonesia : Satu Kajian Empirik, Jurnal Ekonomi \& Studi Pembangunan Vol. 5. No. 2. FE Universitas Muhammadiyah, Yogyakarta. 
22. Sugiyono. 2008. Metode penelitian kuantitatif dan kualitatif dan R\&D. Bandung: CV. Alfabeta.

23. Sukirno, Sadono, 1999, Pengantar Teori Makro Ekonomi, Edisi Kedua, Cetakan Kesepuluh, PT Raja Grafindo Perkasa, Jakarta.

24. Taggart, Douglass Mc; Christoper Findlay; Michael Parkin, 1999. Macroeconomics, Addison-Wesley.

25. Teixeira, Aurora and Natercia Fortuna. 2003. Human Capital, Innovation Capability and Economic Growth, Investigacao - Trabalhos em eurso. No. 131. Julho de 2003.

26. Todaro, Michael P, 2000. Ekonomi pembangunan di Dunia Ketiga, Edisi Ketujuh, Penerbit Erlangga, Jakarta.

27. Wiguna, Van Indra. 2013. Analisis Pengaruh PDRB, Pendidikan Dan Pengangguran Terhadap Kemiskinan Di Provinsi Jawa Tengah Tahun 2005-2010. Jurnal Ilmu Ekonomi, Fakultas Ekonomi dan Bisnis Universitas Brawijaya Malang.

28. Wijaya, Farid, 1997. Seri Pengantar Ekonomika Makro, Edisi ketiga, BPFE UGM, Yogyakarta.

29. Zulhanafi, Hasdi Aimon, Efrizal Syofyan, 2013. Analisis Faktor - Faktor yang mempengaruhi Produktivitas dan Tingkat Pengangguran di Indonesia. Jurnal Kajian Ekonomi, Juli 2013, Vol. II, No.03. 